Doi: $10.4274 /$ vhd. 98698

Viral Hepatitis Journal 2014; 20(3): 95-100

\title{
Waiting for Interferon-free Regimens for Chronic Hepatitis C Patients: A Multicenter Observational Study
}

\author{
Kronik Hepatit C Hastaları için Interferonsuz Tedaviler Bekleniyor: Çok Merkezli Bir \\ Gözlem Çalıșması
}

Rahmet GÜNER1, Zeliha Koçak TUFAN1, Cemal BULUT2, Gülden ERSÖZ3, Ayşe BATIREL4, Bahar KAÇMAZ5, Bircan KAYAASLAN6, Nurcan BAYKAM6, Alpay ARI7, Aziz ÖĞÜTLÜ8, Saygın Nayman ALPAT9, Yasemin DURDU10, Özgür GÜNAL11, Yunus GÜRBÜZ12, Emsal AYDIN13, Selma TOSUN7, Fehmi TABAK5, Association to Combat Viral Hepatitis-Academic Camp Group

1 Yıldırım Beyazıt University Faculty of Medicine, Atatürk Training and Research Hospital, Clinics of Infectious Diseases and Clinical Microbiology, Ankara, Turkey 2Ankara Training and Research Hospital, Clinics of Infectious Diseases and Clinical Microbiology, Ankara, Turkey

3 Mersin University Faculty of Medicine, Departments of Infectious Diseases and Clinical Microbiology, Mersin, Turkey

${ }^{4}$ Kartal Dr. Lutfi Kirdar Training and Research Hospital, Clinics of Infectious Diseases and Clinical Microbiology, Istanbul, Turkey

5/stanbul University Cerrahpaşa Faculty of Medicine, Departments of Infectious Diseases and Clinical Microbiology, Istanbul, Turkey

${ }^{6}$ Ankara Numune Training and Research Hospital, Clinics of Infectious Diseases and Clinical Microbiology, Ankara, Turkey

${ }^{7}$ Bozyaka Training and Research Hospital, Clinics of Infectious Diseases and Clinical Microbiology, Izmir, Turkey

8 Sakarya University Faculty of Medicine, Departments of Infectious Diseases and Clinical Microbiology, Sakarya, Turkey

9 Osman Gazi University Faculty of Medicine, Departments of Infectious Diseases and Clinical Microbiology, Eskişehir, Turkey

10 Eyüp State Hospital, Clinics of Infectious Diseases and Clinical Microbiology, Istanbul, Turkey

11 Gaziosmanpaşa University Faculty of Medicine, Departments of Infectious Diseases and Clinical Microbiology, Tokat, Turkey

12Dışkapı Yıldırım Beyazı t Training and Research Hospital, Clinics of Infectious Diseases and Clinical Microbiology, Ankara, Turkey

13 Kafkas University Faculty of Medicine, Departments of Infectious Diseases and Clinical Microbiology, Kars, Turkey

\section{ABSTRACT}

Objectives: This study aims to determine the reasons for not being able to access treatment of chronic hepatitis $\mathrm{C}(\mathrm{CHC})$ for patients who are followed up without treatment and to serve as a resource for future studies to be conducted to find solutions.

Materials and Methods: The study was planned as a multi-center observational study. Universities, training and research hospitals, and public hospitals from different regions, most of which are members of the Association to Combat Viral HepatitisAcademic Camp, participated in the study. The reasons for untreated follow-up of $\mathrm{CHC}$ patients followed up without treatment were investigated. Patients who were hepatitis $\mathrm{C}$ virus (HCV) RNA negative, who had sustained viral response, and who had been receiving treatment were excluded from the study.

Results: Two hundred and ninety patients diagnosed with $\mathrm{CHC}$ and followed up without treatment were reviewed in detail. The median age was 58 (23-87) years, the number of female patients was $157(54 \%) ; 241$ patients were genotype 1 (83\%), 12 patients were genotype 2, 3 and $4(4 \%), 37$ patients were of unidentified genotypes $(13 \%) ; 174$ patients (60\%) were treatment-naïve; and 14 patients $(12 \%)$ out of the

\section{ÖZET}

Amaç: Bu çalışmada, tedavisiz izlenen kronik hepatit C (KHC) hastalarının, tedavisiz kalma nedenlerinin ortaya konması ve ileriye dönük çözüm önerilerinin oluşturulması amaçlanmıştır.

Gereç ve Yöntemler: Çalışma çok merkezli, gözlemsel çalışma olarak planlandı. Viral Hepatitle Savaşım Derneği-Akademik Kamp üyesi olan merkezlerin çoğunluğunu oluşturduğu farkı bölgelerden üniversite, eğitim araştırma ve devlet hastaneleri çalışmaya katıldı. Tedavisiz izlenen KHC hastalarının tedavisiz izlem nedenleri irdelendi. Hepatit C virüsü (HCV) RNA negatif olan, kalıcı viral yanıtı bulunan ve tedavi almakta olan hastalar çalışma dışı bırakıldı.

Bulgular: KHC tanısı olup tedavisiz izlenen 290 hasta ayrıntılı olarak incelendi. Ortanca yaş 58 (23-87), kadın sayısı 157 (\%54); 241 hasta genotip 1 (\%83), 12 hasta genotip 2, 3 ve $4(\% 4)$, genotipi belirtilmeyen $37(\% 13)$; 174 hasta (\%60) naiv; tedavi deneyimlilerden 14'ü (\%12) kısmi yanıtlı, 41'i (\%36) yanıtsız, 58'i (\%51) relapser idi. 


\section{ABSTRACT}

treatment-experienced patients were partial responders, 41 of them (36\%) were non-responders, and 58 of them (51\%) were relapsers. The most common reasons for untreated follow-ups were as follows: co-morbidity $(28 \%)$, discontinuation of IFN treatment due to side effect/intolerance, or other IFN-related causes such as patient's refusal of treatment due to fear of side effects $(25 \%)$, Health Practice Communiqué (HPC) (14\%), lower fibrosis stage (F0/1) (5\%), and problem of access to drugs (3\%). Gender-wise, the majority of the patients who did not use IFN and who had comorbidities were female $(58 \%$ (n/total $n=42 / 73$ ) and $54 \%$ (n/total $n=44 / 82$, respectively). Five of the 8 patients who had drug access problems were male. Drug access problems due to HPC and other causes were in similar percentages in both sexes.

Conclusion: The most common reasons for $\mathrm{CHC}$ patients not getting treatment were found to be comorbidities, incompliance with HPC, and IFN-related reasons. The high percentage of patients who cannot be treated with IFN because of side effects and comorbidities suggests that new treatment regimes without IFN are necessary, and it is clear that the patient group defined in HPC should be reassessed. (Viral Hepatitis Journal 2014; 20(3): 95-100)

Key words: Hepatitis C, treatment, interferon, Health Practice Communiqué, comorbidity, side effect

Conflict of interest: The authors reported no conflict of interest related to this article.

\section{Introduction}

One hundred and seventy million people worldwide are infected with the hepatitis C virus (HCV), and approximately 350.000 people die due to liver diseases associated with HCV $(1,2)$. In studies reported from our country, the HCV seroprevalence is generally below $1 \%$, and if this is regarded as $0.3-0.4 \%$, it is estimated that $250.000-300.000$ people are HCV-positive $(3,4)$.

Pegylated-interferon/ribavirin (PEG-IFN/RBV) combination is used as the standard treatment of chronic hepatitis $\mathrm{C}(\mathrm{CHC})$ infection. However, this combination is insufficient in providing sustained virological response (SVR) in genotype 1 patient groups, the most common genotype in our country, and cannot be given to some patient groups because of reasons such as certain side effects or comorbidities $(5,6,7)$. New treatments, such as telaprevir and boceprevir that have recently been started to be used in Turkey are new chances for treatment, and their SVR rates seem to be better compared to standard treatment. Unfortunately, these drugs cannot be used alone, but can be used in combination with PEG-IFN/RBV, and the treatment should be ended earlier in some patients due to additional side effects $(8,9)$.

Direct-acting antiviral agents (DAAs) such as sofosbuvir, daclatasvir, asunaprevir, faldaprevir and simeprevir, which have been increasing in number in recent years, provide interferonfree treatment to $\mathrm{CHC}$ patients who cannot be treated due to side effects and comorbidities $(10,11,12,13,14,15)$. The initial results of many studies conducted with combinations of these DAAs with ribavirin and different molecules have been reported, and positive results have been obtained. Studies are ongoing in larger patient groups $(10,11,12,13,14,15,16)$.

\section{ÖZET}

Hastaların en sık tedavisiz izlenme nedenleri sırasıyla: komorbidite (\%28), yan etki/ intolerans nedeniyle IFN tedavisinin bırakıIması ya da yan etki korkusu nedeniyle hastanın tedaviyi reddi gibi IFN ilişkili diğer nedenler (\%25), Sağlık Uygulama Tebliği (SUT) (\%14), düşük fibrozis evresi (F 0/1) (\%5), ve ilaç temini problemiydi (\%3). Cinsiyete göre bakıldığında IFN kullanılamayan ve komorbiditesi olan hastaların çoğunluğunu kadınlar oluşturmaktaydl; sırasıyla \%58 (42/73) ve \%54 (44/82). Ilaç temini problemi olan 8 hastanın $5^{\prime} i$ erkekti. SUT'a bağlı ilaç temini problemi ve diğer nedenler her iki cinsiyette de benzer oranlardaydı.

Sonuç: KHC hastalarının tedavi almamalarının en sık nedenleri ko-morbidite, SUT'a uygunsuzluk ve IFN ilişkili nedenler olarak saptandı. Yan etki ve komorbidite nedeniyle IFN verilemeyen hastaların oranının yüksekliği, IFN'siz yeni tedavi rejimlerinin gerekliliğini ortaya koymakla birlikte, SUT'ta yeni interferonsuz tedavi rejimi uygulanacak hastaların tedavi kriterlerinin belirlenmesi gereklidir. (Viral Hepatit Dergisi 2014; 20(3): 95-100)

Anahtar kelimeler: Hepatit C, tedavi, interferon, Sağlık Uygulama Tebliği, komorbidite, yan etki

Çıkar çatışması: Yazarlar bu makale ile ilgili olarak herhangi bir çıkar çatışması bildirmemiş̧lerdir.

The fact that $\mathrm{CHC}$ patients cannot receive treatment is not only because they have comorbidities or they experience side effects. There are patients who cannot receive treatment because of their insurance reimbursement systems. Every country directs $\mathrm{CHC}$ treatments based on their own healthcare policies and economic plans, and patients' treatment courses may vary depending on the countries they live in. In our country, some of patients followed up without treatment are patients indicated for treatment as per national and international guidelines, but cannot receive treatment as they cannot have access to drugs because of health insurance or Health Practice Communiqué (HPC) $(6,17)$.

This study aims to determine the reasons for not being able to access treatment of $\mathrm{CHC}$ for patients who are followed up without treatment in our country, and to serve as a resource for future studies to be conducted to find solutions.

\section{Materials and Methods}

The study was planned as a multi-center observational study. Universities, training and research hospitals, and public hospitals from different regions, most of which are members of the Association to Combat Viral Hepatitis-Academic Camp, were invited. The clinics that participated in the study were asked questions on the treatment statuses of the $\mathrm{CHC}$ patients they follow up. $\mathrm{CHC}$ patients aged, 18 and older, followed up for any reason, were included in the study; and HCV RNA-negative patients who had sustained viral response after previous treatment and currently receiving treatment, were excluded from the study.

The reasons for not being able to get treatment were divided into sub-groups as patients with comorbidities 
(chronic kidney failure, chronic hematologic and metabolic diseases, transplantations), reasons related to IFN use (early discontinuation of previous treatment due to side effect/ intolerance of IFN, patient's refusal of treatment because of fear of IFN-related side effects), not being able to start treatment as per the HPC, and patients with lower stage fibrosis (F0/1). Causes found to be directly related to IFN were then gathered in the same group. Reasons for not being able to start treatment not within these groups were classified as other reasons.

Microsoft Office Excel was used to gather the data and to form the graphics, and statistical data were calculated using SPSS version 1215.00 for Windows (SPSS inc, Chicago). Median (minimum-maximum) was used to calculate ages from demographics, and gender distribution was specified as percentage. Reasons for follow-up without treatment were specified as figures and percentages.

\section{Results}

A total of 1.024 patient forms from all the sites were reviewed. It was understood that 513 of these patients (50.1\%) were patients with sustained virological response, 290 patients $(28.3 \%)$ were not treated for various reasons, 221 patients $(21.6 \%)$ consisted of patients who were currently receiving treatment or whose sustained virological responses were not assessed yet. Two hundred and ninety patients who could not receive treatment for various reasons were assessed. The general characteristics of the patients are shown in Table 1, and the reasons for their follow-ups without treatment are shown in Figure 1.

The patients were grouped as aged above 65 and aged below 65, and the reasons for their not receiving treatment are shown in Table 2.

Gender-wise, the majority of the patients who did not use IFN and who had comorbidities were female $158 \%$ (n/total $n=42 / 73)$ and $54 \%(n /$ total $n=44 / 82$, respectively). Five of the 8 patients who had drug access problems were male. Drug access problems due to HPC and other causes were in similar percentages in both sexes.

\section{Discussion}

The percentage of the patients followed up at university hospitals, training and research hospitals, and state hospitals in different regions of our country was at a significant level
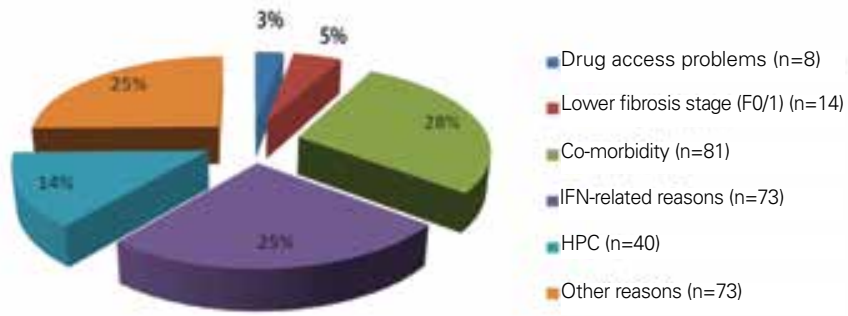

Figure 1. The reasons for chronic hepatitis $C$ patients not receiving treatment compared to the total group of patients. The most common reasons for the said untreated follow-ups were interferonrelated. Not being able to give the current PegIFN/RBV treatment due to comorbidities, patients' being afraid of IFN's side effects, IFN intolerance, and early discontinuation of previous treatment due to side effects were among the major causes.

We are in a period where many changes are made to the literature and guidelines for $\mathrm{CHC}$. Because the number of HIV patients is increasing worldwide, HIV-HCV coexistence and treatment regimes for this are under consideration (18). Studies are also being conducted on immunosuppression treatments needed for various and increasing organ transplants, and management of $\mathrm{CHC}$ in these patients (19). These changes in patients' profiles cause an increase in the percentage of patients with PeglFN/RBV contraindications. In our study, the number of patients who could not be given PeglFN/ RBV because of comorbidities such as chronic renal failure (CRF), HIV infection, transplantation, and chronic hematologic and metabolic diseases was more than one fourth of all the

\begin{tabular}{|c|c|}
\hline Median Age & 58 (min-max: 23-87) \\
\hline Female/Male n (\%) & $157 / 133(54 / 46)$ \\
\hline $\begin{array}{l}\text { Genotypes n (\%) } \\
\text { Genotype } 1 \\
\text { Genotype 1a } \\
\text { Genotype 1b } \\
\text { Genotype 1, subtype not defined }\end{array}$ & $\begin{array}{l}241(83) \\
7(2.4) \\
188(64.8) \\
46(15.9)\end{array}$ \\
\hline Other Genotypes $(2,3,4)$ & $12(4.1)$ \\
\hline Not Specified & $37(12.8)$ \\
\hline Treatment-naïve patients, n (\%) & $174(60.0)$ \\
\hline Compensated cirrhosis, n (\%) & $14(4.8)$ \\
\hline $\begin{array}{l}\text { Status of response to previous treatment* } \\
\text { n/total }(\%) \\
\text { Partial-responders } \\
\text { Non-responders } \\
\text { Relapsers }\end{array}$ & $\begin{array}{l}14 / 114(12.2) \\
41 / 114(36) \\
58 / 114(50.9)\end{array}$ \\
\hline
\end{tabular}

Table 2. Reasons for untreated follow-up based on age

\begin{tabular}{|l|l|l|l|}
\hline \multirow{2}{*}{} & \multicolumn{2}{|l|}{ Age } & \multirow{2}{*}{ Total } \\
\cline { 2 - 3 } & $<65(n=195)$ & $>65(n=94)$ & \\
\hline HPC, n, (\%) & $32(80)$ & $8(20)$ & 40 \\
\hline Co-morbidity, n, (\%) & $54(67)$ & $27(33)$ & 81 \\
\hline $\begin{array}{l}\text { Being unable to use } \\
\text { IFN, n, (\%) }\end{array}$ & $54(74)$ & $19(26)$ & 73 \\
\hline Drug access problem, n, (\%) & $8(100)$ & 0 & 8 \\
\hline F0/1, n, (\%) & $13(93)$ & $1(7)$ & 14 \\
\hline Other, n, (\%) & $34(47)$ & $39(42)$ & 73 \\
\hline
\end{tabular}


patients. Age limit in $\mathrm{CHC}$ treatment is not clearly reported in the literature, however, the majority of the patients followed up in our study group without treatment were younger than 65 years of age. It can be estimated that comorbidities will be reported more commonly in elderly patients. However, $67 \%$ of the patients who could not be treated because of comorbidities in our study group were patients below 65 years of age. The fact that treatment is more commonly indicated in this patient group may be a reason for a more detailed study of patients or a controversial result such as more frequent detection of contraindications or comorbidities.

Although DAAs such as telaprevir and boceprevir provide higher SVR rates compared to the classic PegIFN/RBV regimen, neither of these agents can be used in patients who cannot be given IFN treatment due to their side effects $(20,21)$. These treatments also cause side effects in addition to those of PegIFN/RBV. Anemia, dry skin, rash, diarrhea, hemorrhoids, anorectal discomfort, metallic taste in the mouth, nausea, and vomiting are the major side effects $(8,9,20,21,22,23)$. Although there is now hope that triple therapy regimes can be used especially in treatment-experienced patients, the treatment may have to be discontinued due to these side effects, and therefore, management of side effects is extremely important in the follow-up of these patients (24).

Considering the patients who cannot use IFN because of the side effects of treatment regimes with IFN and comorbidities, the biggest development in the literature last year was interferon-free treatment regimes. Studies have reported that interferon-free treatment regimes provide a cure rate of more than $90 \%$ (25). In the PEARL II Study, AbbVie regimen/ribavirin (AbbVie regimen: fixed-dose combination of ABT-450/ritonavir (150/100 mg) co-formulated with ABT-267 (25 $\mathrm{mg})$, dosed once daily, and ABT-333 $(250 \mathrm{mg})$ with and without ribavirin) was used in treatment-naïve, non-cirrhotic, genotype $1 \mathrm{~b}$ patients as interferon-free treatment, and high SVR was achieved at the end of the 12-week treatment (26). Even in cirrhotic patients, who are difficult to treat, the response rates were reported as 92-96\%. In the SYNERGY Study, three different interferon-free treatment regimes were tried, and SVR rates of $95-100 \%$ were achieved at the end of the 6 to 12-week treatment (27). In the PHOTON 1 Study, interferonfree treatment was tried in patients coinfected with HIV-HCV (28). At the end of the 24-week treatment with "Sofosbuvir" (Sovaldi, Gilead), a nucleotide analog polymerase inhibitor used once daily, 76\% SVR was achieved in genotype $1 \mathrm{CHC}$ patients, $88 \%$ in genotype 2 patients, and $90 \%$ in genotype 3 patients. The biggest development in $\mathrm{CHC}$ treatment was the rapid changes made to the treatment guidelines following FDA approval of simeprevir and sofosbuvir in the USA (29). Some of the studies conducted with sofosbuvir, which seems to be the perfect treatment regime in treatment-experienced and treatment-naïve patients, HIV-HCV-coinfected patients, and pretransplant and post-transplant patients for its high virological response rates and low side effect rates when used alone or in combination, are ongoing $(30,31,32)$.

While new treatment regimes promise big hopes, treatment options for $\mathrm{CHC}$ patients may be limited by costs and economic policies (33). There is an assistance program for patients in the United States of America for boceprevir and telaprevir, and the treatment costs of some patients, whose insurances do not cover these treatments, may be paid by this program $(34,35)$. In some countries in the Middle East and North Africa, new treatments are paid for a limited number of patients, patients are compared and those who need treatment the most with regards to their clinical manifestations and laboratory values are given these treatments. In some countries including European countries, patients can pay for their own costs and buy their own treatments. Reimbursement conditions for the drugs used for $\mathrm{CHC}$ treatment in our country are specified by HPC. The number of patients (patients who have not responded to first treatment or who have received the standard treatment twice) without access to PegIFN/RBV treatment because of HPC practices is high. While it is yet unclear how new treatment regimes will appear in the HPC, the HPC practices will have to be reassessed with national and international guidelines. There are some company-based projects in the United States of America that provide support to patients who have problems gaining access to drugs in their treatment regimes containing telaprevir and boceprevir. The fact that the number of patients in our study with problems gaining access to drugs due to reasons other than HPC is quite low shows that there is no need to establish such support programs for now.

Our study had some limitations. Not all the comorbidities could be specified in detail. Therefore, specific comorbidities and other related factors might have been omitted when listing the reasons for not receiving treatment. Additionally, there is another issue that should be underlined. As there are patients whose treatments are still ongoing and whose SVRs cannot be calculated yet, the SVR rates given here should be regarded as the end-of-treatment SVR rates of all the treated patients.

\section{Conclusion}

The most common reasons for $\mathrm{CHC}$ patients not receiving treatment were found to be comorbidities, incompliance with HPC, and IFN-related reasons. The high percentage of patients who cannot be treated with IFN because of side effects and comorbidities suggests that new IFN-free treatments are needed.

\section{References}

1. Mohd Hanafiah K, Groeger J, Flaxman AD, Wiersma ST. Global epidemiology of hepatitis $C$ virus infection: new estimates of age-specific antibody to hepatitis C virus seroprevalence. Hepatology. 2013;57(4):1333-1342.

2. Hepatitis C: fact sheet no. 164. Geneva: World Health Organization, 2012 Available at: http://www.who.int/ mediacentre/factsheets/fs164/en Access Date: 10th February 2013.

3. Dilsiz G, Yenicesu I, Belen FB, Celik B, Ozturk G. Trends in hepatitis $B$ and hepatitis $C$ virus seropositivity among blood donors over 15 years screened in the blood bank of a university hospital. Transfus Apher Sci. 2012;47(1):95-100.

4. Mıstık R. Hepatit $C$ Virüs enfeksiyonunun epidemiyolojisi. In: Tabak F, Tosun S,eds. Viral Hepatit 2013. Istanbul Tıp Kitabevi, İstanbul 2013;pp 81-112. 
5. Guner R, Kocak Tufan Z, Guven T, Hacıosmanoglu D, Yilmaz GR, Tasyaran MA. Hepatit C tedavisinde PEG IFN/RBV ile yüksek EVY düşük KVY. XII. Ulusal Hepatit Kongresi Antalya 2014. Abstract.

6. Guner R, et al. Kronik Hepatit C Enfeksiyonunda Tedavisiz Izlem Nedenleri: Çok Merkezli Çalışma XII. Ulusal Hepatit Kongresi Antalya 2014. Abstract.

7. Dogan UB, Atabay A, Akin MS, Yalaki S. The comparison of the efficacy of pegylated interferon $\alpha-2 a$ and $\alpha-2 b$ in chronic hepatitis C patients with genotype 1. Eur J Gastroenterol Hepatol. 2013;25(9):1082-1085.

8. Di Bisceglie A, et al. Virologic Outcomes and Adherence to Treatment Algorithms in a Longitudinal Study of Patients with Chronic Hepatitis C Treated with Boceprevir (BOC) or Telaprevir (TVR) in the United States (HCV-TARGET). 64th Annual Meeting of the American Association for the Study of Liver diseases, November 1-5, 2013, Washington, USA; abstract 41.

9. Zeuzem S1, Andreone P, Pol S, Lawitz E, Diago M, Roberts S, Focaccia R, Younossi Z, Foster GR, Horban A, Ferenci P,

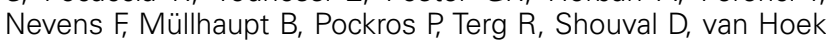
B, Weiland O, Van Heeswijk R, De Meyer S, Luo D, Boogaerts G, Polo R, Picchio G, Beumont M; REALIZE Study Team. Telaprevir for treatment of HCV infection. N Eng J Med. 2011;362:24172428.

10. Forns $X$, et al. Simeprevir (TMC435) with peg-interferon $\alpha-2 a$ / ribavirin for treatment of chronic HCV genotype 1 infection in patients who relapsed after previous interferon-based therapy: efficacy and safety in patient sub-populations in the PROMISE phase III tria64th Annual Meeting of the American Association for the Study of Liver diseases, November 1-5, 2013, Washington, USA; abstract 1092.

11. Jacobson I, et al. STARTVerso3: A randomized, double-blind, placebo-controlled Phase III trial of faldaprevir in combination with pegylated interferon alfa-2a and ribavirin in treatmentexperienced patients with chronic hepatitis C genotype-1 infection. 64th Annual Meeting of the American Association for the Study of Liver diseases, November 1-5, 2013, Washington, USA; abstract 1100 .

12. Zeuzem S, et al. Sofosbuvir + Ribavirin for 12 or 24 Weeks for Patients with HCV Genotype 2 or 3 : the VALENCE trial. 64th Annual Meeting of the American Association for the Study of Liver diseases, November 1-5, 2013, Washington, USA; abstract 1085 .

13. Jacobson I, et al. SVR results of a once-daily regimen of simeprevir (TMC435) plus sofosbuvir (GS-7977) with or without ribavirin in cirrhotic and non-cirrhotic HCV genotype 1 treatmentnaïve and prior null responder patients: The COSMOS study. 64th Annual Meeting of the American Association for the Study of Liver diseases, November 1-5, 2013, Washington, USA; abstract LB3.

14. Dufour JF, et al. Interferon-Free Treatment with Faldaprevir, Deleobuvir (BI 207127) and Ribavirin in SOUND-C3: 95\% SVR12 in HCV-GT1b. 64th Annual Meeting of the American Association for the Study of Liver diseases, November 1-5, 2013, Washington, USA; abstract 1102.

15. Gane E, et al., Once Daily Sofosbuvir/Ledipasvir Fixed Dose Combination with or without Ribavirin: Data from the ELECTRON trial. 64th Annual Meeting of the American Association for the Study of Liver diseases, November 1-5, 2013, Washington, USA; abstract 73.

16. Lawitz $E$, et al. Once Daily Sofosbuvir/Ledipasvir Fixed Dose Combination with or without Ribavirin Resulted in $\geq 95 \%$ Sustained Virologic Response In Patients with HCV Genotype 1,Including Patients with Cirrhosis: the LONESTAR trial. 64th Annual Meeting of the American Association for the Study of Liver diseases, November 1-5, 2013, Washington, USA; abstract 215 .
17. Sosyal güvenlik kurumu sağlık uygulama tebliğinde değişiklik yapılmasına dair tebliğ. Resmî Gazete Sayı : 2877726 Eylül 2013.

18. Sulkowski M, et al. All-Oral Therapy With Sofosbuvir Plus Ribavirin For the Treatment of HCV Genotype 1, 2, and 3 Infection in Patients Co-infected With HIV (PHOTON-1). 64th Annual Meeting of the American Association for the Study of Liver diseases, November 1-5, 2013, Washington ,USA; abstract 212.

19. Charlton MA, et al. Sofosbuvir and Ribavirin for the Treatment of Established Recurrent Hepatitis C Infection After LiverTransplantation: Preliminary Results of a Prospective, Multicenter Study. 64th Annual Meeting of the American Association for the Study of Liver diseases, November 1-5, 2013, Washington,USA; abstract LB2.

20. Poordad F, McCone J Jr, Bacon BR, Bruno S, Manns MP, Sulkowski MS, Jacobson IM, Reddy KR, Goodman ZD, Boparai N, DiNubile MJ, Sniukiene V, Brass CA, Albrecht JK, Bronowicki JP; SPRINT-2 Investigators. Boceprevir for untreated chronic HCV genotype 1 infection. N Engl J Med. 2011;364(13):11951206.

21. De Meyer S, Dierynck I, Ghys A, Beumont M, Daems B, Van Baelen B, Sullivan JC, Bartels DJ, Kieffer TL, Zeuzem S, Picchio G. Characterization of telaprevir treatment outcomes and resistance in patients with prior treatment failure: results from the REALIZE trial. Hepatology. 2012;56(6):2106-2115.

22. Manns MP, McCone J Jr, Davis MN, Rossaro L, Schiff E, Shiffman ML, Bacon B, Bourliere M, Sulkowski MS, Bruno $S$, Balart L, Bronowicki JP, Kwo P, Poordad F, Felizarta F, Reddy KR, Helmond FA, Sings HL, Pedicone LD, Burroughs M, Brass CA, Albrecht JK, Vierling JM. Overall safety profile of boceprevir plus peginterferon alfa- $2 \mathrm{~b}$ and ribavirin in patients with chronic hepatitis C genotype 1: a combined analysis of 3 phase 2/3 clinical trials. Liver Int. 2014;34(5):707-719.

23. Guner R, Tufan ZK. Telaprevir use in a chronic hepatitis $C$ patient with hemophilia. Eur J Gastroenterol Hepatol. 2014;26(2):248.

24. Cacoub P, Bourliere M, Lübbe J, Dupin N, Buggisch P, Dusheiko G, Hezode C, Picard O, Pujol R, Segaert S, Thio B, Roujeau JC. Dermatologic side effects of hepatitis $c$ and its treatment; patient menagement in the era of direct-acting antivirals. $J$ Hepatol. 2012;56:455-463.

25. Frellick M. New Interferon-Free Drugs for Hep C Show High Cure Rates. Available at: http://www.medscape.com/ viewarticle/821393 Acess date: 18 th March 2014.

26. Lawitz E, Hezode C, Varunok P, Thuluvath PJ, Baykal T, Kapoor M, Lovell SS, Wang T, Pilot-Mathias T, Vilchez RA, Bernstein B. Interferon- and Ribavirin-free Regimen of ABT-450/r + ABT-267 in HCV Genotype 1b-infected Treatment-naive Patients and Prior Null Responders. 64th Annual Meeting of the American Association for the Study of Liver Diseases (AASLD 2013). Washington, DC, November 1-5, 2013. Abstract 74.

27. Kohli $A$, et al. Combination Oral, Ribavirin Free, Antiviral Therapy to Optimize Treatment Outcomes for Hepatitis C GT-1 Treatment Naïve Patients: Interim Results from the NIAID SYNERGY Trial. 64th Annual Meeting of the American Association for the Study of Liver diseases, November 1-5, 2013, Washington, USA; abstract LB8.

28. Sulkowski $M$, et al. All-Oral Therapy With Sofosbuvir Plus Ribavirin For the Treatment of HCV Genotype 1, 2, and 3 Infection in Patients Co-infected With HIV (PHOTON-1). 64th Annual Meeting of the American Association for the Study of Liver diseases, November 1-5, 2013, Washington, SA; abstract 212.

29. World Health Organization. Guidelines for the screening, care and treatment of persons with hepatitis C infection. April 2014. 
30. Phase III HIV/HCV Co-Infection Daclatasvir (DCV)+ Sofosbuvir (SOF) (ALLY 2)Sof. Available at: http//www.clinicaltrials.gov (ClinicalTrials.gov Identifier:NCT02032888) Acess date: 18 th March 2014.

31. Curry MP, et al.,Pretransplant Sofosbuvir and Ribavirin to Prevent Recurrence of HCV Infection after Liver Transplantation 64th Annual Meeting of the American Association for the Study of Liver diseases, November 1-5, 2013, Washington, USA; abstract 213.

32. Charlton MA, et al. Sofosbuvir and Ribavirin for the Treatment of Established Recurrent Hepatitis C Infection After LiverTransplantation: Preliminary Results of a Prospective,
Multicenter Study. 64th Annual Meeting of the American Association for the Study of Liver diseases, November 1-5, 2013, Washington,USA; abstract LB2.

33. Hagan LM, Sulkowski MS, Schinazi RF. Cost analysis of sofosbuvir/ribavirin versus sofosbuvir/simeprevir for genotype $1 \mathrm{HCV}$ in interferon ineligible/intolerant individuals. Hepatology. 2014;60(1):37-45.

34. Telaprevir Patient Assistance Program. Available at: http://www. natap.org/ Acess date: 18th March 2014.

35. Boceprevir\&Peginterferon Patient Assistance Programs. Available at: http://www.natap.org/ Acess date: 18th March 2014. 